\title{
PENERAPAN MODEL PEMBELAJARAN STANDING BANNER LEARNING UNTUK MENINGKATKAN HASIL BELAJAR MAHASISWA PADA MATAKULIAH BIOLOGI KONSERVASI
}

\author{
Marta Dinata $^{1)}$ Al Khudri Sembiring ${ }^{2)}$ \\ ${ }^{1) 2)}$ Pendidikan Biologi FKIP Universitas Lancang Kuning \\ Email $^{1)}$ : martadinata@unilak.ac.id \\ email $^{2)}$ :alkhudri_s@unilak.ac.id
}

\begin{abstract}
ABSTRAK: Model pembelajaran ini merupakan pengembangan model pembelajaran kooperatif yang mana dalam kelas mahasiswa dibagi dalam kelompok yang terdiri dari 2 sampai 5 orang. Sebelum melakukan pembelajaran setiap kelompok diberi tugas sesuai sub materi untuk membuat banner sebagai media dan bahan diskusi. Untuk pertemuan berikutnya kelompok 1 akan mempresentasikan sub materi 1 dengan bantuan media standing banner. Kemudian kelompok yang kurang paham dengan penjelasan diberi kesempatan bertanya. Setelah itu kelompok tersebut akan menyimpulkan pembelajaran tersebut. Kemudian dosen akan merefleksi pembelajaran yang telah dijelaskan. Model pembelajaran standing bunner learning diharapkan dapat membantu mahasiswa untuk memahami pembelajaran yang bersifat abstrak, memfokuskan perhatian mahasiswa pada pembelajaran dan meningkatkan hasil belajar mahasiswa.Metode penelitian yang digunakan adalah penelitian tindakan kelas (PTK) yang dilakukan di prodi pendidikan biologi pada matakuliah biologi konservasi. Penelitian ini dilakukan pada bulan Februari 2020 sampai dengan Oktober 2020. Objek penelitian adalah mahasiswa yang mengambil mata kuliah biologi konservasi yang berjumlah 25 orang. Parameter penelitian ini adalah hasil belajar, aktifitas mahasiswa dan aktifitas dosen. Analisis data menganalisa persentase daya serap, ketuntasan individu, aktifitas dosen dan mahasiswa. Dari data yang dianalsis dapat disimpulkan bahwa penerapan standing banner dalam pembelajaran dapat meningkatkan hasil belajar biologi, baik untuk aspek kognitif, afektif maupun psikomotorik mahasiswa pada pokok bahasan biokonservasi. Ratarata daya serap siswa pada siklus I 79.20 (Cukup) sedangkan pada siklus II ratarata naik menjadi 86.13 (Baik). Ketuntasan belajar siswa pada siklus I 72\% (Tidak Tuntas) dan pada siklus II naik menjadi 92\% (Tuntas). Berdasarkan uji-t bahwa terdapat perbedaan yang signifikan antara UH1 dan UH2
\end{abstract}

Kata Kunci: Model pembelajaran standing bunner learning, Media Choose Number, Task Orientation, Hasil Belajar, Biokonservasi

\section{PENDAHULUAN}

Pendidikan adalah pembelajaran

pengetahuan, keterampilan, dan

kebiasaan sekelompok orang yang

diturunkan dari satu generasi ke generasi berikutnya melalui
pengajaran, pelatihan, atau

penelitian. Pendidikan sering terjadi

di bawah bimbingan orang lain, 
tetapi juga memungkinkan secara otodidak. Setiap pengalaman yang memiliki efek formatif pada cara orang berpikir, merasa, atau tindakan dapat dianggap pendidikan. Pendidikan umumnya dibagi menjadi tahap seperti prasekolah, sekolah dasar, sekolah menengah dan kemudian perdosenan tinggi.

Pengembangan model pembelajaran sangatlah penting dan dalam pembelajaran yaitu model pembelajaran standing banner learning. Model pembelajaran ini merupakan pengembangan model pembelajaran kooperatif yang mana dalam kelas mahasiswa dibagi dalam kelompok yang terdiri dari 2 sampai 5 orang. Sebelum melakukan pembelajaran setiap kelompok diberi tugas sesuai sub materi untuk membuat bunner sebagai media dan bahan diskusi. Untuk pertemuan berikutnya kelompok 1 akan mempresentasikan sub materi 1 dengan bantuan media standing bunner. Kemudian kelompok yang kurang paham dengan penjelasan diberi kesempatan bertanya. Setelah itu kelompok tersebut akan menyimpulkan pembelajaran tersebut. Kemudian dosen akan merefleksi pembelajaran yang telah dijelaskan. Model pembelajaran standing banner learning diharapkan dapat membantu mahasiswa untuk memahami pembelajran yang bersifat abstrak, memfokuskan perhatian mahasiswa pada pembelajaran dan meningkatkan hasil belajar mahasiswa.

\section{METODE PENELITIAN}

Penelitian ini merupakan penelitian tindakan kelas yaitu penelitian yang dilakukan dosen terhadap proses pembelajaran dikelasnya sendiri dengan tujuan meningkatkan aktivitas dan hasil belajar mahasiswa. Penelitian ini terdiri dari 2 siklus dan setiap siklus terdiri atas 2 kali pertemuan.

Metode penelitian yang digunakan adalah penelitian tindakan kelas (PTK) yang dilakukan di prodi pendidikan biologi pada matakuliah biologi konservasi. Penelitian ini dilakukan pada bulan Februari 2020 sampai dengan Oktober 2020. Objek penelitian adalah mahasiswa yang mengambil mata kuliah biologi konservasi yang berjumlah 25 orang. Parameter penelitian ini adalah hasil 
belajar, aktifitas mahasiswa dan aktifitas dosen. Analisis data menganalisa persentase daya serap, ketuntasan individu, aktifitas dosen dan mahasiswa.

\section{HASIL DAN PEMBAHASAN}

Ketuntasan belajar mahasiswa berdasarkan analisa tes hasil ulangan harian, ketuntasan belajar mahasiswa secara individu dan secara klasikal pada siklus I dan siklus II setelah menggunakan metode standing banner learning media choose number dengan task orientation dapat dilihat pada Tabel 1 berikut ini:

Tabel 1.

Ketuntasan Belajar Mahasiswa Pada

\begin{tabular}{|c|c|c|c|}
\hline \multicolumn{2}{|c|}{$\begin{array}{c}\text { Ketuntasan belajar } \\
\text { mahasiswa }\end{array}$} & Siklus I & Siklus II \\
\cline { 2 - 4 } & $\begin{array}{c}\text { UH I } \\
(\%)\end{array}$ & $\begin{array}{c}\text { UH II } \\
(\%)\end{array}$ \\
\hline \multirow{2}{*}{ Individual } & Tuntas & $18(72)$ & $23(92)$ \\
\cline { 2 - 4 } & $\begin{array}{c}\text { Tidak } \\
\text { Tuntas }\end{array}$ & $7(28)$ & $2(8)$ \\
\hline \multicolumn{2}{|c|}{ Jumlah mahasiswa } & 25 & 25 \\
\hline \multicolumn{2}{|c|}{ Ketuntasan klasikal } & $\begin{array}{c}\text { Tidak } \\
\text { Tuntas }\end{array}$ & Tuntas \\
\hline
\end{tabular}

Siklus I dan Siklus II

Berdasarkan Tabel 1. dapat

dijelaskan bahwa ketuntasan belajar mahasiswa secara individu pada siklus I mahasiswa yang tuntas sebanyak 18 orang (72\%), sedangkan mahasiswa yang tidak tuntas 7 orang
(28\%), secara klasikal kelas tersebut dikategori tidak tuntas. Sedangkan siklus II mahasiswa yang tuntas sebanyak 23 orang (92\%) dan mahasiswa yang tidak tuntas 2 orang (8\%) secara klasikal kelas diketegori tuntas. Tercapainya ketuntasan belajar mahasiswa secara individu ini disebabkan oleh mahasiswa telah dapat memahami cara belajar dengan menggunakan metode standing banner learning media choose number dengan task orientation dan melaksanakan aktifitas-aktifitas pada indikator pengamatan serta mengerti terhadap materi pembelajaran yang diberikan oleh dosen sehingga tugas dapat dikerjakan dengan baik, ketidaktuntasan individu disebabkan oleh mahasiswa yang bersangkutan tidak melaksanakan aktifitas-aktifitas pada indikator pengamatan dengan baik dan disebabkan juga faktor internal mahasiswa seperti kecerdasan, perhatian, minat, dan bakat.

Hasil belajar mahasiswa meningkat karena mahasiswa mulai aktif belajar dengan menggunakan metode standing banner learning. Dengan menggunakan media choose 
number mahasiswa dapat memilih sendiri pertanyaan mana yang akan dijawab tanpa mengetahui isi pertanyaannya (Yuningsih, 2012). Task orientation (arahan tugas) merupakan usaha untuk memberikan motivasi mahasiswa dalam belajar dengan memberi tugas diawal mahasiswa dapat labih aktif dalam pembelajaran yang di ajarkan dosen (Fraser dalam Acnesia, 2013).

\section{KESIMPULAN}

Berdasarkan hasil penelitian dan hasil analisis data, dapat disimpulkan bahwa disimpulkan bahwa penerapan standing banner dalam pembelajaran dapat meningkatkan hasil belajar biologi, baik untuk aspek kognitif, afektif maupun psikomotorik mahasiswa pada pokok bahasan biokonservasi. Rata-rata daya serap siswa pada siklus I 79.20 (Cukup) sedangkan pada siklus II rata-rata naik menjadi 86.13 (Baik). Ketuntasan belajar siswa pada siklus I $72 \%$ (Tidak Tuntas) dan pada siklus II naik menjadi $92 \%$ (Tuntas). Berdasarkan uji-t bahwa terdapat perbedaan yang signifikan antara UH1 dan UH2

\section{REFERENSI}

Arikunto, Suharsimin. (2002). Prosedur Penelitian: Suatu Pendekatan Praktek. Jakarta: Rienka Cipta.
Muizaddin, R dan Santoso, B. (2016). Model Pembelajaran Core Sebagai Sarana Dalam Meningkatan Hasil Belajar Mahasiswa. Jurnal pendidikan manajemen perkantoran. Volume 1, nomor 1, Agustus 2016 halaman 235 - 243

Djamarah, dan Aswan Zain. (2002).

Strategi Belajar Mengajar. Jakarta:

Rineka Cipta. Djamarah, Syaiful. (2003) Psikologi Kependidikan.

Bandung: Remaja Rosda Karya.

Ibrahim, Muslimin. (2006).

Pembelajaran Kooperatif.

Surabaya: UNESA University Press.

Sudjana, Nana. (2005). Penilaian hasil proses belajar mengajar.

Bandung: Remaja Rosdikarya.

Surya, Mohammad. (2004). Psikologi Pembelajaran dan Pengajaran. Yogyakarta: Pustaka Pelajar.

Triarini, I.D. (2005). "Peran Kognitif dan Metakognitif dalam Proses Pembelajaran". Jurnal Psikologi Sosial Vol. 13 No. 3

Suprijono, Agus. (2009). Cooperative Learning: Teori dan Aplikasi PAIKEM. Yogyakarta: Pustaka Pelajar. 